\title{
Opatrzność i wróg. O Janie Zawickim i jego tragedii Jeftes
}

Jeszcze do niedawna prawdziwe było stwierdzenie, że Jan Zawicki to autor, o którego życiu niczego pewnego nie wiemy. Udało się odnaleźć go w szeregach scholarów Akademii Krakowskiej. W albumie studentów Uniwersytetu Krakowskiego ${ }^{1}$ pod rokiem 1580 widnieje wpis Jana Stanisława ${ }^{2}$ Zawickiego z Zawidza w diecezji płockiej, opatrzony późniejszą adnotacją: „Proscriptus ab <Universita $>$ te ob multas in $<$ a $>$ ctis contentas causa” („Usunięty z Uniwersytetu z powodu wielu przypadków, znajdujących się w aktach") ${ }^{3}$. Notatka, sporządzona w metryce uniwersyteckiej, odsyła do Akt rektorskich. Proces Zawickiego toczył się przed sądem uniwersyteckim, gdyż uczelnie akademickie cieszyły się wówczas licznymi swobodami gwarantowanymi przez prawo kanoniczne. Jak podaje już na początku osiemnastego wieku Jędrzej Kitowicz:

Akademie publiczne miały bez wątpienia i mają przywileje immunitatis (jako to: krakowska, zamojska i wileńska), iż się nie godzi tak studentów, jak i profesorów w sprawie jakiej osobistej pociągać do żadnego sądu, tylko do zwierchrzności szkolnej. ${ }^{4}$

\footnotetext{
1 Por. Album studiosorum Universitatis Cracoviensis, t. III: Ab anno 1551 ad annum 1606, editionem curavit A. Chmiel, Cracoviae 1904, s. 116.

2 Zawicki na kartach tytułowych swoich dzieł używał konsekwentnie tylko jednego imienia: Jan.

3 Jeśli nie zaznaczono inaczej, wszystkie tłumaczenia pochodzą od Autora artykułu.

4 J. Kitowicz, Opis obyczajów za panowania Augusta III, oprac. R. Pollak, wyd. 3 przejrzane, Wrocław 1970, s. 97.
} 
Z akt wynika, że pozew przeciw Janowi Zawickiemu został sporządzony 10 maja 1586 roku. Po tygodniu skreślono go z listy studentów. 17 maja sąd akademicki wydał wyrok, którego sentencja brzmi:

My Piotr Gorczyński, doktor obojga praw, kanonik krakowski, główny rektor studiów, w obliczu trybunału i mając przed oczyma Jedynego Boga i Jego dzieła, na wniosek akademii w sprawie wichrzyciela Jana Zawickiego, przyjętego w poczet członków jako studenta i scholara Akademii Krakowskiej, uznajemy na mocy naszego wyroku za winnego jako gwałciciela i przywłaszczyciela w cudzych domach i dopuszczającego się w nich gwałtu na kobietach zamężnych. I na mocy prawa, i z powodu tego zajścia wobec nieposłusznego wyrokowi i niepomnego przysięgi, złożonej wobec nas i przełożonego naszej szkoły, postanawiamy z tego powodu jako kłamliwego buntownika i nieposłusznego dekretowi, i odrzucającego pozew rektora zaocznie — jako że nie był obecny przy wydaniu wyroku - ostatecznie skazać go na opuszczenie uniwersytetu i pozbawić wszelkich uprawnień do pełnienia jakichkolwiek funkcji. Publicznie ogłaszamy i przyrzekamy, i odbieramy, i pozbawiamy go swobód i przywilejów, i nietykalności, należnej studentom uniwersytetu, oraz z szeregów studentów i scholarów krakowskich wyrzucamy i do jego pierwotnego stanu — świeckiego - przywracamy, aby usunąć zgorszenia i odpędzić rozpustę wraz z zakazem przebywania na krakowskim Kazimierzu, Kleparzu i innych pobliskich miejscach. Przekazujemy stosowne dokumenty krakowskiemu Uniwersytetowi i przyrzekamy karać popełnione przestępstwa i ekscesy — zamierzone w jakimkolwiek miejscu by nie były, kierując się prawem i sprawiedliwością tegoż urzędu, na wzór właśnie tego, który więcej nie jest i nie będzie podległy rektorowi Uniwersytetu Krakowskiego. ${ }^{5}$

Przypadek Zawickiego nie należał do rzadkości na tle obyczajów panujących wśród studenckiej braci końca XVI wieku. Mimo surowego regulaminu miejscem awantur były szczególnie bursy, a wśród scholarów zdarzały się kradzieże żywności oraz mienia — rzeczy codziennego użytku i książek ${ }^{6}$. Henryk Barycz podaje, że

5 Por. Acta rectoraria ab anno 1580 ad annum 1618, rkps. Archiwum Uniwersytetu Jagiellońskiego, sygn. 18, k. 111; por. też ibidem, k. 107.

6 Por. H. Barycz, Historia Uniwersytetu Jagiellońskiego w epoce humanizmu, Kraków 1935, s. 642. 
Ostatnią, najwyższą karą była relegacja, czyli tzw. proskrypcja, którą też coraz częściej musiano stosować w ostatniej ćwierci wieku za nieposłuszeństwo władzy rektorskiej, nieodsiedzenie więzienia, napady na domy mieszczańskie i gwałty w nich popełniane. ${ }^{7}$

Lata nauki Zawickiego przypadają na okres schyłkowy świetności Akademii Krakowskiej, która już na początku XVII wieku nie będzie tak ważnym ośrodkiem naukowym. Przebieg studiów poety, jak się zdaje, nie przedstawiał się imponująco, skoro w przeciągu sześciu lat Jan z Zawidza nie uzyskał stopnia bakałarza ${ }^{8}$. Studenci wpisujący się na uniwersytet mieli zwykle od 15 do 20 lat. Na podstawie wpisu do metryki uczelnianej ustalić można, że Zawicki przyszedł na świat około 1560-1565 roku. Gniazdem rodowym poety był Zawidz.

O samym rodzie Zawickich nic nie wiemy, poza tym, że sygnowali się herbem Jastrzębiec. Paprocki w Herbach rycerstwa polskiego czyni lakoniczną wzmiankę: „Zawidzkie z wielkiego Zawidza — dom znaczny" . Nie wiadomo też, gdzie kształcił się Jan z Zawidza, nim przekroczył progi Wszechnicy Jagiellońskiej. Musiał bowiem już posiadać elementarną wiedzę ogólną i znajomość łaciny, które umożliwiały mu dalsze studiowanie. Może uczęszczał wcześniej do szkoły parafialnej znajdującej się w Jeżewie, oddalonym o trzy kilometry od Zawidza. Do opuszczenia rodzinnych stron skłoniła poetę prawdopodobnie tradycja lokalna - w XVI i XVII wieku studiowało na królewskim uniwersytecie od trzech do czterech osób z Zawidza ${ }^{10}$. Na mocy wyroku z 17 maja 1586 roku Jan Zawicki opuścił Akademię Krakowską.

Pozostałe informacje biograficzne rekonstruować można jedynie na podstawie dedykacji zawartych w utworach poety. Otóż w roku 1587 w krakowskiej oficynie Jana Januszowskiego wychodzi tragedia Jeftes. Utwór poświęcił poeta Stanisławowi Mińskiemu z Mińska (ok.

Ibidem, s. 650-651.

8 Student rozpoczynający swoją karierę w Akademii na wydziale artium, zwykle po dwóch latach, kiedy spełniał określone warunki, mógł przystąpić do egzaminu, który kończył się nadaniem stopnia bakałarza, a po kolejnych dwóch latach mógł ubiegać się o stopień magistra tegoż wydziału (por. R. Wroczyński, Dzieje oświaty polskiej do roku 1795, Warszawa 1996, t. I, s. 50). Materiały archiwalne nie wykazują, by Jan Zawicki był dyplomowany.

9 B. Paprocki, Herby rycerstwa polskiego, wyd. K. J. Turowski, Kraków 1858-1860, s. 183.

10 Por. Album studiosorum... 
1561-1607). W dedykacji przedstawiał go jako człowieka obdarzonego przez Boga licznymi przymiotami:

\author{
[...] bo cię Bóg nadarzył \\ tym, co dziś w ludziech jest nowiną wielką. \\ Uprzedzasz lata klejnoty drogiemi, \\ poważna ludzkość buja nad któremi \\ i ta-ć zniewala wszystki ludzie prawie. \\ (Dedykacja, w. 4-8) ${ }^{11}$
}

Przyszły podkanclerzy koronny był już wówczas osobą sławną i powszechnie szanowaną. Dzięki mecenatowi biskupa Piotra Dunin Wolskiego znalazł się w otoczeniu królewskim i miał za sobą podróż do Rzy$\mathrm{mu}^{12}$, do którego przyszło mu jeszcze powrócić po latach — tym razem w roli postulatora procesu beatyfikacyjnego Jacka Odrowąża ${ }^{13}$. Paprocki w Herbach... komplementuje Mińskiego jako „męża uczonego, który mores hominum et urbes widział i wiedział" ${ }^{14}$. Stanisław z Mińska słynął z oddania Kościołowi katolickiemu i cieszył się popularnością w środowisku kontrreformacyjnym. Swoje utwory dedykowali mu przedstawiciele reformy katolickiej: Abraham Bzowski, Krzysztof Warszewicki i Fabian Birkowski ${ }^{15}$. W tym kontekście może zatem nie dziwić fakt pominięcia przez Jana Zawickiego na karcie tytułowej Jeftesa informacji o tym, że jego dzieło to przekład łacińskiej tragedii protestanckiego humanisty ${ }^{16}$.

11 Wszystkie cytaty z Jeftesa przytaczam za unikatowym egzemplarzem Biblioteki Zakładu Narodowego im. Ossolińskich: J. Zawicki, Jeftes, Kraków 1587, druk. Łazarzowa, sygn. BOss XVI. Qu. 2446.

12 Por. S. Gruszecki, Miński Stanistaw, w: Polski Stownik Biograficzny, t. XXI/1, Wrocław 1976, s. 320-322.

13 Zob. Sposób odprawowania poselstwa z obedyjencyja do Rzymu, wyd. J. Korzeniowski, Kraków 1889.

14 B. Paprocki, op. cit., s. 530.

15 Sam Miński również zajmował się twórczością poetycką. Dochowała się do naszych czasów sporządzona przez niego parafraza epody Horacego Beatus ille, qui procul negotiis... Utwór zachował się m.in. w rękopisie Biblioteki PAN w Krakowie (sygn. 1273, k. 11-13; przedruk w: Staropolska poezja ziemiańska. Antologia, oprac. J. S. Gruchała, S. Grzeszczuk, Warszawa 1988 („Biblioteka Poezji i Prozy”), s. 181-183).

16 Warto w tym kontekście przytoczyć uwagę Janiny Abramowskiej (Ead., Ead i Fortuna. O tragedii renesansowej w Polsce, Wrocław 1974 („Studia Staropolskie”, t. XL), 
Wkrótce po 24 stycznia 1588 roku Zawicki napisał cykl poetycki zatytułowany Charites stowieńskie. Utwór pozbawiony jest informacji o miejscu i dacie wydania ${ }^{17}$. Na podstawie zawartych w nim aluzji łatwo jednak ustalić czas powstania: niedługo po 24 stycznia 1588 roku $^{18}$, kiedy to Zamoyski pokonał w bitwie pod Byczyną wojsko austriackiego pretendenta do tronu polskiego — arcyksięcia Maksymiliana Habsburga. Charites... dedykował poeta Janowi Zamoyskiemu ${ }^{19}$ (1542-1605), co z czasem stało się źródłem łatwej, choć do dziś niepotwierdzonej hipotezy, jakoby Zawicki był związany z mecenatem hetmana wielkiego koronnego ${ }^{20}$. Sama dedykacja nie jest dostatecznym powodem, by uważać, że poeta z Zawidza nawiązał relacje z Zamoyskim. Bitwa pod Byczyną odbiła się głośnym echem w polskiej literaturze, a wielki hetman był z tej okazji opiewany w utworach okolicznościowych i obdarowywany wieloma upominkami literackimi ${ }^{21}$. Wystarczy wspomnieć tu choćby Pieśń Kalijopy stowieńskiej na teraźniejsze pod Byczyna zwycięstwo Stanisława Grochowskiego czy Andrzeja Schoneusa Trzy ody do Pana

s. 79): „Wybitny szkocki humanista, który w latach sześćdziesiątych opowiedział się jawnie po stronie kalwinizmu, stanowił autorytet ideowy i moralny dla czytelnika protestanckiego, stąd większość protestantów niemieckich wymienia jego nazwisko z najwyższymi pochwałami. W Polsce końca lat osiemdziesiątych było to nazwisko kontrowersyjne i to zapewne zdecydowało o wyglądzie karty tytułowej polskiego Jeftesa".

17 Zachował się m.in. w egzemplarzu Biblioteki Narodowej, sygn. BN XVI. Qu. 6621.

18 Por. K. i S. Estreicherowie, Bibliografia polska, t. XXXIV, z. 2, Kraków 2000, s. 449.

19 Zob. J. Nowak-Dłużewski, Okolicznościowa poezja polityczna w Polsce. Zygmunt III, Warszawa 1971, s. 24-27.

20 Pogląd ten, jak się zdaje, upowszechnił się głównie dzięki pracom Stanisława Łempickiego, który omawia Charites stowieńskie wśród utworów poetów należących do kręgu mecenatu Jana Zamoyskiego. Zob. S. Łempicki, Medyceusz polski XVII w. (Rzecz o mecenacie Jana Zamoyskiego), Zamość 1929, s. 23-24; Id., Renesans i humanizm $w$ Polsce. Materiaty do studiów, wstęp K. Budzyk, Warszawa 1952, s. 340; Id., Mecenat wielkiego kanclerza. Studia o Janie Zamoyskim, wybór i wstęp S. Grzybowski, Warszawa 1980, s. 517; Id., Medyceusz polski XVII w. (Rzecz o mecenacie Jana Zamoyskiego), w: Szymon Szymonowic i jego czasy. Rozprawy i studia, red. S. Łempicki, Zamość 1929, s. 119-120.

21 Szerzej na ten temat zob. M. Kaczmarek, Bitwa pod Byczynq w literaturze polskiej, w: Bitwa pod Byczyna w 1588 roku. Materiaty z sesji naukowej zorganizowanej w Byczynie w 400-lecie zwycięstwa Jana Zamoyskiego nad Maksymilianem Habsburgiem, red. M. Lis, Opole 1990, s. 77-93. 
Jana Zamoyskiego, kanclerza wielkiego koronnego i hetmana wielkiego koronnego, triumfatora. Zapewne cykl pieśniowy Charites stowieñskie wyszedł spod pras tej samej krakowskiej drukarni, w jakiej zaledwie przed rokiem został wydany Jeftes. Na tym urywa się ślad po Janie z Zawidza. Kolejne lata jego życia nie są znane. Nie mamy nawet informacji o dacie i miejscu śmierci. Trudno jednak wyobrazić sobie, by poeta aktywny literacko, który w ciągu zaledwie dwóch lat wydał dwa dzieła, nagle zaprzestał działalności pisarskiej. Być może więc po 1588 roku Jan Zawicki umiera.

Charites... łączy z Jeftesem nie tylko, co się już rzekło, miejsce wydania. Oba teksty wykazują liczne paralele i powiązania zarówno na płaszczyźnie tematycznej, jak i leksykalnej. Już samo obrazowanie męstwa Jeftego, „które precz strachy z ojczyzny zrzuciło” (w. 573), ma swoje rozwinięcie w Charites...:

[...] cny hetmanie, którego staranie

płacz, nędze, dziwne błędy, ludzkie narzekanie

ojczyzny mojej zdjęło. ${ }^{22}$

Podobnie nagana życia człowieka leniwego, właściwego zwierzętom: „Bo kto tu gnuśnie a w ospalstwie żywie, / żywie jak nieme źwierzęta właściwie” (w. 591-592) w Charites... została wzbogacona o apoteozę życia cnotliwego:

Bo kto na świecie tu cnotliwie żyje,

A nie — w gnuśności, ni w swej woli tyje

Jak nieme źwierzę, ma już obiecany

Wiek nieprzetrwany. ${ }^{23}$

Tragedia Jeftes osnuta na kanwie biblijnej opowieści o wodzu Galaadczyków (przedstawionej w 13 rozdziale Księgi Sędziów) ${ }^{24}$ z ko-

22 Wszystkie cytaty z Charites... podaję za egzemplarzem przechowywanym w Bibliotece Narodowej (ed. cit., s. 10).

23 Ibidem, s. 20.

$24 \mathrm{Na}$ temat analizy filologicznej tego fragmentu Biblii por. ks. W. Pikor, Jefte paradygmat niespetnionego wtadcy (Sdz 10, 6-12, 7), „Roczniki Teologiczne”, 2006, LIII, z. 1, s. 35-57. Omówienie różnych ujęć historii Jeftego w literaturze oraz innych sztukach zob. Leksykon postaci biblijnych. Ich dalsze losy w judaizmie, chrześcijaństwie, 
nieczności została wzbogacona o nowe elementy. Jefte, nim wyruszył na wojnę, złożył Bogu przysięgę, że jeśli odniesie zwycięstwo nad Ammonitami, odda Jahwe na ofiarę całopalną to, co pierwsze wyjdzie mu naprzeciw, gdy będzie wracał do domu. Okazało się, że spotkał jedyną córkę. W tragedii nazywa się ona Ifis.

Dramat Jana Zawickiego jest, jak wiadomo, tłumaczeniem łacińskiej tragedii George'a Buchanana (1506-1582), mającej nieco bardziej rozbudowany tytuł: Jephthtes, sive votum. Pierwsza edycja dzieła szkockiego humanisty ukazała się w Paryżu w roku 1554. Już w trzy lata po nim pojawiło się wznowienie (Paryż, 1557). Tragedia szybko została przełożona na języki narodowe: francuski (translacja Claude'a de Vesel, 1566) ${ }^{25}$, niemiecki (Jonasz Bitner, 1569) ${ }^{26}$, włoski (Giustiniano, 1583) ${ }^{27}$ i polski (Jan Zawicki, 1587). Jephthes doczekał się także translacji na język węgierski (Jllyefari, 1590).

Nie wiemy, z którego łacińskiego wydania korzystał polski poeta. W Bibliotece Uniwersytetu Jagiellońskiego do dziś znajdują się szesnastowieczne egzemplarze Jephthes $a^{28}$ oraz innych dzieł Buchanana ${ }^{29}$, co niewątpliwie świadczy o tym, że twórczość szkockiego humanisty cieszyła się w ówczesnej Polsce dużą popularnością. Warto wspomnieć tu o innym polskim Jeftem, wystawionym w obecności biskupa Baranowskiego w Pułtusku 23 sierpnia 1599 roku. Wchodził on w skład niezachowanego do naszych czasów rękopisu różnego rodzaju dialogów, komedii oraz tragedii, pisanych wierszem polskim i łacińskim. Musimy polegać jedynie na relacji ks. Załęckiego, który przekazuje, że zaginiony Jefte „składa się z pięciu aktów. Wstęp i treści wszystkich aktów, chory

islamie oraz sztukach plastycznych, red. M. Baian, współprac. U. Kraut, I. Lenz, przeł. J. Zychowicz, Kraków 1995.

25 Wkrótce ukazały się kolejne edycje: Florena Chréstiena (1567), wznawiana sześciokrotnie (!), A. Mage'a de Fileflemina (1601) i Pierra Brinona (1614).

26 Powstały cztery tłumaczenia: Marcina i Sylwestra Steinerów (1571), Jana Titeliusa (1592), Jerzego Dedekena (1592), Hermana Niceohorusa (1604).

27 Ukazało się jeszcze drugie tłumaczenie na włoski — Bargagliego (1600).

28 Jest to m.in. cimelium, wspólne wydanie Jephthesa z tragedią Alcestis (drukarnia Iosiasa Rihela, 1567), sygn. BUJ Cim 1855.

29 Kilka różnych edycji Paraphrasis psalmorum Davidis, np. wydanie Iosiasa Rihela z 1566, sygn. BUJ Neo-lat. 1310. 
do nich dodane i domówienie — wierszem polskim, reszta — wierszem łacińskim" ${ }^{30}$. Dalej ks. Załęcki podaje:

Pięknie jest wyrażone przywitanie córki w akcie trzecim, gdzie Jefte powraca z tryumfem po zwycięstwie nieprzyjaciół; pięknie głęboki smutek i rozpacz, gdy widzi córkę swoją wesoło bieżącą; pięknie jej ciekawość, dlaczego ojciec tak smutny. ${ }^{31}$

O łacińskich epejsodiach Jeftego nie możemy powiedzieć, czy były zależne od tragedii Buchanana i w jakim stopniu. Załęcki przytacza natomiast kilka fragmentów polskich, głównie ze stasimonów, które wykazują pewne analogie do dramatu Zawickiego. Oto fragment jednej z pieśni:

Niemasz nic pewnego,

Niemasz nic stałego.

Dziś piękna pogoda,

Jutro z gradem woda.

[...]

Tak ma Bóg na pieczy

Wszystkie ludzkie rzeczy,

Iż z miodem radości

Mięsza żółć żałości. ${ }^{32}$

Ten sam model szczęścia, zmiennego jak pogoda, oraz zmieszanych z żółcią rozkoszy odwzorowuje trzecia pieśń chóru u Zawickiego:

Takowy jest los wieku naszego,

że w nim nic niemasz ustawicznego.

Jako za słońcem chmura wychodzi,

tak smutek radość wnet z siebie rodzi.

30 Bibliografja. Wiadomość o rękopisie z XVI wieku znalezionym na kościele niegdyś jezuitów, a teraz benedyktyńskim w Puttusku (udzielona przez x. Zatęckiego), w: Biblioteka starożytna pisarzy polskich, t. VI, zebrał K. W. Wójcicki, wyd. 2, Warszawa 1854, s. 327. Por. także W. Hahn, Literatura dramatyczna w Polsce XVI wieku, Lwów 1906, s. 98.

31 Cyt. za: Bibliografija. Wiadomość o rękopisie z XVI wieku..., s. 327.

32 Cyt. za: ibidem, s. 325. 
[...]

Niemasz tu żadnej rozkoszy prawej,

niemasz fortuny długo łaskawej.

Wszytkim rozkoszam żółć jest przysadą.

(w. 773-778, 781-783).

Występuje też scena pożegnania matki przez córkę, jak ma to miejsce u Buchanana-Zawickiego:

Najmilsza matko, już się rozstaniemy

i różnych krajów włości dostaniemy. ${ }^{33}$

Zależność tragedii Jana z Zawidza od łacińskiego oryginału Buchanana wykazał w 1845 roku Walerian Kalinka ${ }^{34}$. Z czasem wysunięto nawet pretensję pod adresem samego Zawickiego, opartą na zwykłej nieznajomości rzeczy, jakoby poeta dopuścił się plagiatu ${ }^{35}$.

Problem metody translatorskiej Jana z Zawidza przewijał się również w nowszych badaniach nad Jeftesem. Na uwagę zasługują tu prace Janiny Abramowskiej ${ }^{36}$ oraz Mirosławy Hanusiewicz-Lavallee ${ }^{37}$. Autorka niezastąpionej rozprawy o tragedii renesansowej, Janina Abramowska, omawiając utwór Zawickiego w rozdziale Niewinny grzesznik przed milczacym Bogiem, twierdzi, że „zgodnie ze zwyczajami epoki jest on przeróbką, ale przeróbką dość wierną, zachowuje układ scen, rysunek postaci, ideowo-moralny sens konfliktu"38. Uściśliła tę formułę Mirosława Hanusiewicz-Lavallee. Szczegółowe porównanie przez badaczkę polskiego Jeftesa z łacińskim pierwowzorem wykazało, iż „dzieło Zawickiego jest raczej adaptacją niż ścisłym tłumaczeniem, dość swobodnym

33 Cyt. za: ibidem, s. 328.

34 Por. W. Kalinka, O trajedyi „Jephthes” i mniemanym jej autorze Janie Zawickim, „Orędownik Naukowy” VI (1845), nr 17, s. 135-136 oraz nr 18, s. 143-144.

35 Por. R. Łopiński, Jeftes Jana Zawickiego i Jeftes Buchanana, „Biblioteka Warszawska” 1881, t. II, s. 115-128.

36 Por. J. Abramowska, op. cit., s. 61-89.

37 Por. M. Hanusiewicz-Lavallee, Tragedia rozumu i pobożności. „Jephthes Buchanana -Zawickiego, „Odrodzenie i Reformacja w Polsce”, 2008, LII, s. 27-50.

38 J. Abramowska, op. cit., s. 79-80. 
nawet na tle XVI-wiecznych obyczajów translatorskich"39. Ponadto Hanusiewicz-Lavalle zauważyła:

\begin{abstract}
Właściwe łacińskiemu oryginałowi napięcie emocjonalne i dynamika są w dużej mierze pochodną precyzyjnych, opartych na stychomytii i dystychomytii dialogów postaci; $\mathrm{w}$ istocie przecież tragedia jest tragedią racji, dramatycznym zwarciem argumentów, a zatem ich artykulacja i konfrontacja staje się głównym źródłem napięcia. Zawickiemu z rzadka udaje się odtworzyć tę dynamikę dialogów. Najczęściej rozwija poszczególne kwestie do rozmiaru co najmniej dystychu, czasem nawet łączy kwestie i argumenty w jednej wypowiedzi, nie zważając na to, że w oryginale wypowiadają je ideowi przeciwnicy. ${ }^{40}$
\end{abstract}

Kontekst historyczny tragedii szkockiego humanisty i przyczyny recepcji utworu w językach wernakularnych stały się przedmiotem pracy Magdaleny Ryszki-Kurczab, która za źródło popularności dzieła uważa wojny na tle religijnym we Francji ${ }^{41}$.

Jak już podkreślano ${ }^{42}$, podczas gdy Buchanan eksponuje mitologiczny wystrój w swoim dziele, wysiłek polskiego tłumacza zmierza do zatarcia śladów antyku. Tak więc „Tartarum” zmienia Zawicki raz na „nocne ciemności” (w. 97), innym razem na „ogień naznaczony” (w. 723) lub „okrutne piekło” (w. 810). „Aurora” tłumaczy jako „różane zorze” (w. 209), „Olympum” oddaje jako „wierzch nieba” (w. 1012). Jest tak, jakby poeta z Zawidza unikał w Jeftesie sprzecznego z genezą historii biblijnej antykizowania. To znamienne, że w Charites... przyjmuje odwrotne rozwiązanie poetyckie — właśnie na pierwszy plan wysuwa sztafaż antyczny. Przywołuje postaci mitologiczne oraz historyczne. Sięga też po starożytne realia geograficzne i korzysta z epitetów

39 M. Hanusiewicz-Lavallee, op. cit., s. 33.

40 Ibidem, s. 35-36.

41 Autorka pisze: „Gdzie zatem należałoby upatrywać źródeł tak fenomenalnej kariery Jeftesa? Byłabym skłonna szukać wyjaśnienia we wstępie, a dokładnie w Prologu sztuki, poprzedzającym właściwe zdarzenia dramatyczne i wygłaszanym, bez jakichkolwiek prób stworzenia iluzji scenicznej, przez Anioła - typową personne protetique — nie pojawiającą się nigdzie więcej w dramacie. Prolog przynosi konkretną wizję historiozoficzną, adekwatną wobec konfliktów religijnych, czy właśnie wojny domowej, która ogarnęła Francję w połowie XVI wieku” (M. Ryszka-Kurczab, Literackie i pozaliterackie konteksty szesnastowiecznej tragedii "Jephthes" George'a Buchanana / Jana Zawickiego, „Terminus” VII (2008), z. 1-2, s. 177).

42 Por. J. Abramowska, op. cit., s. 81-82. 
złożonych, odnoszących się do bóstw mitologicznych, np.: „złotowłosy Febus”, „Klio złotousta”, „wartogłowy bóg” (Mars), „skrzydłonogi szkapa" (Pegaz). Jednak chyba i tu plejada bóstw starożytnych zdaje się wprowadzać poetę w zakłopotanie; wyznaje:

Panu, który nasze rzeczy
Ma i miał w ten czas na pieczy,
Gdyśmy sie z Niemcy ścierali,
Którzy nam Koronę brali,
Słusznie jest winną cześć dawać.
$[\ldots]$
Bo tak barzo ważne rzeczy
Bellonie przyznać nie g rzeczy.

Mało w tragedii Zawickiego subtelności:

Zatym sie prędko wracaj, bo cię ku ofierze

ślub od ojca wydany bez wymówki bierze.

(w. 501-502)

— mówi Jefte do swej córki — jakby polski poeta nie dostrzegał, że Buchanan nie zaznacza, co stanie się przedmiotem ofiary:

Huc rursus ad nos post brevi revertere.

Adesse oportet te sacrificio statim. ${ }^{44}$

W innym miejscu u Zawickiego czytamy: „Niedługo mą osobą cieszyć się będziecie” (w. 477), u Buchanana zaś mamy: „Nobis pariet absentiam haec praesentia" ${ }^{45}$.

Jednak i polski poeta nie tylko potrafi oddać kunszt frazy oryginału, o czym świadczy przykład tak subtelnego zabiegu jak instrumentacja głoskowa w wersie 91: „Światu wszystkiemu światłości służąca”"

43 J. Zawicki, Charites stowieńskie, s. 11.

44 Jephthes, sive votum authore Georgio Buchanano Scoto, Parisiis MDLIIII (w oficynie Gustawa Morela), s. 20.

45 Ibidem, s. 19.

46 Wszystkie podkreślenia w cytowanych tekstach pochodzą od Autora artykułu. 
gdy u Buchanana: „O sol, o vaga $l u$ min a $l u$ na e”, ale i sam tworzy ładne gry słowne:

Nigdy żadnemu $s z c z e ́ s ́ c i$ e tak $s z c z e s ́$ li i e
nie służy, aby tegoż też złośliwe
dosiąc nie miało [...].
(w. 609-611)

Gdy człowiek n i e rad słucha, kiedy mu kto $r a d z i$, często żal za niem chodzi, często mu to wadzi.

(w. 745-746)

W nas, których $l u d z ́ \mathrm{~m}$ i stworzył, niech $l u d z$ k ość panuje. (w. 834)

Jan z Zawidza w swej tragedii sugestywnie posługuje się antropomorfizacją, charakterystyczną dla stylu biblijnego ${ }^{47}$, co daje w rzeczywistości ludzki obraz Boga. W tragedii Buchanana cecha ta jest całkowicie nieobecna. U Zawickiego Stwórca — podobnie jak człowiek — działa i patrzy, choć nie słyszy.

Chór panien izraelskich, przeniknięty atmosferą radości z odniesionego zwycięstwa, wypowiada formułę dziękczynienia za to, że „Wszystko święta prawica Jego rozproszyła / i nierychłym potomkom pokój uczyniła" (w. 287-288). Jefte, w chwili tryumfu, ufny w Opatrzność, wyraża przeświadczenie: „[...] a Tyłaskawe Twe oko / przeciw nam, Panie, wynosisz wysoko" (w. 377-378), a w momencie kulminacji rozpaczy kieruje do Boga prośbę: „[...] jeśliże przedsięwzięcie moje / w czym ucieszyło święte ucho Twoje, / nie odwracaj go" (w. 705-706). Brak też w tekście Buchanana wyrażeń o zabarwieniu emocjonalnym, za pomocą których polski tłumacz buduje klimat uczuciowy utworu. Należą do nich deminutiva („dziatki”, „dziecię”, „dziecina”), zaimki dzierżawcze podkreślające podmiotowość („matko ma”, „miła córo moja” „moja córo”) oraz nagromadzone środki leksykalne

47 Podobna cecha występuje w Psatterzu Dawidowym Kochanowskiego. Szerzej o tym por. J. Ziomek, Wstęp, w: J. Kochanowski, Psatterz Dawidów, oprac. J. Ziomek, Wrocław 1960 (BN I, 174), s. 86-87. Por. także A. Karpiński, Renesans, Warszawa 2007, s. 114-115; Studia teologiczne, t. III: Obraz Boga w Psatterzu, red. ks. A. Eckmann, ks. S. Łach, ks. A. Tronina, Lublin 1982. 
wyrażające cierpienie: „frasunek”, „kłopoty”, „krzywda”, „łzy”, „płacz”, „smutek”, „trudności”, „żal”, „żałość”. W wypowiedziach matki pojawiają się w różnych konfiguracjach triady: „płacze, kłopoty, frasunki” (w. 109), „płacze, łzy i kłopoty” (w. 1091), „kłopoty, żale, trudności” (w. 1143). Wśród epitetów na szczególną uwagę zasługują: „miły”: „ojcze miły” (w. 1105), „miła córo moja” (w. 1121) oraz „ciężki”: „ciężkie łzy” (w. 1010), „frasunki ciężkie” (w. 99), „ciężkie narzekanie” (w. 1116).

Często Zawicki sięga po porównanie o dwu członach składowych, z charakterystyczną dążnością do paralelizmu ${ }^{48}$. Nasilenie tych tendencji obserwuje się przede wszystkim w miejscach, gdzie pojawiają się rozważania natury filozoficznej, propagujące idee neostoickie, na których polskiemu poecie szczególnie zależało, czemu dał wyraz w dedykacji skierowanej do Mińskiego:
Chciałem wyrazić szczęścia odmiennego obraz, w którym był ojciec z córą swoją.
Dziś jest hetmanem sławnym, jutro śmiechem nieprzyjacielskim i ludzkim igrzyskiem.

(Dedykacja, w. 9-12)

Są to najczęściej porównania, składające się z dwóch lub czterech wersów, dla których ramę stanowią wskaźniki zespolenia: „jako” oraz „tak”. W miejscach, gdzie występuje większa liczba tego typu porównań, oprócz paralelizmu, wzmacnia się także anaforyczność, np.:

Jako się wały biją w bystrej wodzie,

tak ustępuje przygoda przygodzie.

Jak o dzień za dniem zwykłym płynie torem,

t a k sie frasunki ścigają z uporem.

(w. 119-122)

Jak o za słońcem chmura wychodzi,

tak smutek radość wnet $\mathrm{z}$ siebie rodzi.

(w. 775-776)

48 Por. K. Wilczewska, Wstęp, w: Staropolski dramat biblijny, t. V: Dramaty biblijne XVI wieku, Lublin 2000, s. 41. 
Jako za ciepłym, wesołym czasem

wnet następuje zima z niewczasem,

tak płocho szczęście wszystko plundruje,

co nisko było, wzgórę wskakuje.

(w. 777-780)

Inną charakterystyczną cechą języka poetyckiego polskiego autora są epitety tautologiczne („harda pycha”, „strach lękliwy”, „frasowne troski”, „nieumiejętność ślepa”, „krnąbrna pycha”, „frasunek ciężki”, „łaska miłościwa”, „duma zauchwała”) oraz zaprzeczone („nieutulony”, „nieprzebyty”, „niezbożny”, „nieprzetrwany”, „niewychwalony”, „nieprzepłacony”, „nieobroniony”). Nagromadzenia, bazujące na zestawieniu obok siebie wyrazów o podobnej semantyce („sily i mocy”, „czci i chwały”, „łaski i hojności”, „uczeńszy i bieglejszy”), dysonanse (przyrównanie człowieka leniwego do zwierzęcia i trupa, w. 591-594), przerzutnie oraz inwersje sygnalizują już nową poetykę — epoki baroku.

Dotychczas nie podjęto głębszej refleksji na temat zawartości filozoficznej, która, obok teologicznej, decyduje, jak sądzę, o wymowie ideowej dramatu. W tragedii odbiło się echem pytanie o odpowiedzialność Boga za los Jeftego. Problem ten został rozwiązany (a może tylko pominięty?...) na gruncie Bożej pedagogiki:

\footnotetext{
A Jeftes by nie wspyśniał, mieszkając w pokoju, wnet szwank podejmie w domu żałosny z frasunkiem, bo to straci, co ma mieć w starości ratunkiem, iż dla skutku szczęśliwej wojny to ślubował, że „co mi drogę zajdzie, będę ofiarował Bogu ofiarą krwawą [...]”.

(w. 44-49)
}

Uwagi bohaterów utworu i stawiane przez nich pytania nie pozwalają czytelnikowi jednak zawiesić lektury na tej moralistycznej interpretacji. Warto zwrócić uwagę na kilka wypowiedzi.

Poznajemy wodza Galaadczyków, kiedy obiecuje złożenie Bogu ofiary z tego, co mu „wprzód zajdzie drogę". Jefte w modlitewnej formule wyraża optymistyczne przeświadczenie, że Bóg sam może oczyścić jego obietnice: 
Acz trudno oddać rózne dary Twoje, lecz Ty, pochopne bacząc chęci moje, w dobre obrócisz, choćby liche były, bo Ty umacniasz każdego z nas siły. [...] Świat, gwiazdy, niebo, to-ć wszystko hołduje, a okrom Ciebie pociechy nie czuje.

(w. 435-438; 445-446)

Ta prosta w gruncie rzeczy wiara w Boską Opatrzność, poparta renesansowym przekonaniem o istnieniu kosmicznej harmonii, załamuje się z chwilą spotkania z córką i szybko przechodzi w zwątpienie. Wybrzmi to szczególnie mocno podczas rozmowy z Symachem. Jefte skieruje wówczas do Boga pełną wątpliwości modlitwę:

Ale Ty, który straszliwemi gromy, ziemią i piekłem, niebieskiemi domy władniesz, jeśliże przedsięwzięcie moje w czym ucieszyło święte ucho Twoje, nie odwracaj go i w tej mej potrzebie, a przypuść prośby głos mojej do siebie. (w. 703-708)

Zauważmy, że zdanie bohatera jest warunkowe (,jeśliże przedsięwzięcie moje / w czym ucieszyło święte ucho Twoje"). Wyraża nie tylko wątpliwość co do tego, czy Bóg w ogóle przyjął obietnicę, ale i wyłącza zarazem Stwórcę całkowicie z odpowiedzialności za nią. Skoro milczy, może znaczyć, że nie przyjął... Buchanan nie wprowadził tu deus ex machina, a tym samym nie ułatwił interpretacji teologicznej. Nie dopuścił do głosu Boga, pozostawiając cień niepewności.

Podczas gdy Jefte twierdzi, iż stan wysoki „fundament ma swój na upadzie”, a szczęśliwy jest los tylko tych, których Bóg pozostawił w niskim stanie i „strzeże swym okiem”, Symach przekonuje go, że właśnie dzięki Bożej interwencji z człowieka biednego stał się mężem sławnym i powinien to uważać za znak Opatrzności:

Tobie jest wszystko z Bożej mocy dano, to, co może być w człeku pożądano: 
sława uczciwa, zwycięstwo ozdobne, żeś w łasce Pańskiej, masz znaki podobne.

Bądź wdzięcznym łaski i Bożej hojności, pomniąc, że to masz z Jego życzliwości.

(w. 597-602)

Z podobnym stwierdzeniem spotykamy się jeszcze raz:

[...] ten żywot my nalepszy mamy,

w którym na<i>mniej frasowanych trosk znamy,

jakiś ty znalazł z Bożego przejźrzenia -

pełen czci, chwały i dobrego mienia,

zwycięstwa, złota [...].

(w. 669-673)

— poucza Symachus. Już za chwilę, gdy dowie się, co „dla skutku szczęśliwej wojny" ślubował jego przyjaciel, skoryguje swój sąd, mówiąc: "Wszak przedsięwzięcie ni e jest to od Pana” (w. 692). Odtąd rozmówca Jeftego nie tylko odrzuca całkowicie myśl o odpowiedzialności Boga za sytuację przyjaciela, ale i uporczywie szuka innej odpowiedzi:

Głowa jest moja, żem ci dobrze radził,

że tak nie padło, wróg jakiś zawadził.

Skutek ma w ręku szczęście wszystkich rzeczy,

a gdy źle padnie, wnet pytają, gdzie ci,

którzy nam rady w sprawach dodawają,

za co albo dank, albo hańbę mają.

(w. 739-744)

Symachus przypisuje „wrogowi” i „szczęściu”, a zatem kategoriom świeckim, odpowiedzialność za tragedię przyjaciela. Warto przyjrzeć się tym pojęciom.

Komentatorzy literatury szesnastego wieku objaśniają 'wroga' często jako 'los' czy też 'fatum'. Nie jest to jednak wyjaśnienie dostateczne. W szesnastym wieku wyraz 'wróg' w powyższym znaczeniu występuje rzadko, częściej natomiast oznacza 'szatana' i 'wróżbitę'. Pisał o tym przed laty Wiktor Weintraub w studium „Fraszka” w tragicznej tonacji: 
Nie sposób znaleźć 'wroga' u żadnego z wykształconych renesansowych pisarzy, u Górnickiego, Kromera, Orzechowskiego, czy później u Szymonowica. Natomiast pojawia się ono w tekstach nawiązujących do popularnej tradycji, takich jak Historyja o chwalebnym Zmartwychwstaniu Pańskim czy Ludycyje wieśne. Najwyraźniej dla szesnastowiecznej świadomości językowej nie należało ono do zasobów polerowanej literackiej polszczyzny. Współcześników Kochanowskiego 'wróg' musiał zatem zaskakiwać jako zjawisko nieoczekiwane w jego poezji. Kojarzył się z wyobrażeniami o ciemnej, groźnej mocy oraz popularnych praktykach magicznych. ${ }^{49}$

Niełatwo oprzeć się wrażeniu, że Zawicki, świadomy wagi znaczenia terminu „wróg” u poety z Czarnolasu, uczynił aluzję do Trenu XI, w którym czytamy: „Nieznajomy w róg jakis miesza ludzkie rzeczy, I Nie mając ani dobrych, ani złych na pieczy" (w. 5-6) ${ }^{50}$. Jan z Zawidza, podobnie jak Kochanowski, opatrzył „wroga” zaimkiem nieokreślonym („jakiš”), co podkreśla tajemniczość tej nieznanej mocy ${ }^{51}$. W polskim Jeftesie „wróg” pojawia się jeszcze dwukrotnie. Wspomina o nim Storge. Nękana złymi przeczuciami, mówi:
[...] i ty, świadoma, Nocy, żalów moich,
niech za nakryciem czarnych skrzydeł twoich
wywiem sie, jeśliże co przeciwnego
potka mą córę od wrogu złośn e go,
głowę mą pierwej pod ziemne ciemności
zepchnicie [...].
(w. 93-98)

Na podstawie apostrofy można odnieść wrażenie, że Storge wspomina o wróżbie. Pod osłoną nocy pragnie „wywiedzieć się” tego, co spotka jej córkę, gdyż, jak powszechnie uważano, właśnie pora nocna była najstosowniejszym czasem, by oddawać się praktykom magicznym, które miały na celu przepowiadanie przyszłości. Warto też zauwa-

49 W. Weintraub, „Fraszka” w tragicznej tonacji, w: Id., Rzecz czarnoleska, Kraków 1977, s. 314. Por. Id., O poezji religijnej Jana Kochanowskiego, w: Polska liryka religijna, red. S. Sawicki, P. Nowaczyński, Lublin 1983, s. 56-57.

50 J. Kochanowski, Treny, oprac. J. Pelc, wyd. 15 zmien., Wrocław 1986 (BN II, 1). Wszystkie cytaty z Trenów pochodzą z tej edycji.

51 Por. W. Weintraub, „Fraszka”..., s. 312. 
żyć, że „wróg” pojawia się tu w kontekście piekła („nocne ciemności”) i dodatkowo otrzymuje epitet „złośny”, tj. 'zły', co niewątpliwie jest synonimem szatana.

O interwencję prosi tajemniczych wrogów również zrozpaczony Jefte. Jak i poprzednio, także i w tym kontekście pojawiają się świat podziemny i piekło:
A ty, ziemio, która masz być lana cnotliwych członków krwią panieńskich świeżą a gorącą, niech mię wrogowie w ciemne jaskinie twe wtrącą! Poźrzy mię, niechaj zginę z niewinną mą ręką, bo sie i okrutnego piekła z jego męką nie boję, mężobójcą bym jedno do niego nie wszedł, bo już mam w domu wszystki męki jego. (w. 806-812)

Nie mniej mroczną od wroga siłą jest w tragedii Fortuna, która, jak mówi Symachus, „skutek ma w ręku [...] wszystkich rzeczy”. Posiada taki sam zakres władzy jak Opatrzność. Słowa przyjaciela Jeftego, traktujące o bogini szczęścia, brzmią polemicznie wobec formuły Chirona: „U Boga szczęście w ręku” (w. 441), pojawiającej się na kartach Satyra Kochanowskiego. Gorzką prawdę o panowaniu Fortuny wyraża także Storge:
Teraz mię srogie Szczęście nawałnością swoją zrzuciło prawie z góry i z nadzieją moją. Wynióswszy mię wysoko, na dół mię z igrzyskiem pchnęło, wiodąc myśli me opak z naśmiewiskiem. (w. 1025-1028)

Kapryśna bogini szczęścia nie tylko kieruje światem, ale i rządzi się tymi samymi mechanizmami co demon. Najpierw fałszywie zwodzi człowieka, a gdy ten już uwierzy, że mu sprzyja, prowadzi go ku niechybnemu upadkowi ${ }^{52}$. Do problematyki filozoficznej przyjdzie jeszcze powrócić.

\footnotetext{
52 Por. E. Lasocińska, „Cnota sama z madrościa jest naszym żywotem”. Stoickie pojęcie cnoty w poezji polskiej XVII wieku, Warszawa 2003 („Studia Staropolskie. Series
} 
W przedostatniej pieśni, w apostrofie do Jeftego, chór wspomina o tajemniczym nieprzyjacielu:
A ciebie widząc zgwałconym, twój n i e przyjaciel na złość się śmieje i szydząc z ciebie, głową swą chwieje, a ty twarz twoję umywasz łzami, nędzniku, z twemi obietnicami. (w. 981-985)

Fragment ten, jak się okazuje, utkany został z „ciemnych” wersetów Księgi Psalmów. Nieprzyjaciel Jeftego posiada cechy prześladowców Mesjasza z Psalmu 22 - urąga i szyderczo potrząsa głową. Identyczny obraz cierpień Sprawiedliwego powtórzy ewangelista, opisując drwiny z Chrystusa podczas agonii na krzyżu (Mk 15, 29). Jefte, słysząc obelgi, łzami umywa twarz podobnie jak bohater Psalmu 6 - swoje łoże (Ps 6, 7).

W kolejnych wersach tej samej pieśni chóru pojawia się motyw mgły: „Czarna mgła błędu cię zaślepiła, / a światła widzieć nie dopuściła” (w. 986-987). To nie tylko wyraz niemocy duchowej Jeftego, który nie rozpoznał prawdy („światła), ale — przede wszystkim — synonim jego grzechu („błędu”), w jakim się pogrążył poprzez nieroztropną obietnicę. Wątek „mgły grzechu” pojawia się w literaturze staropolskiej także u tzw. poetów metafizycznych — Sebastiana Grabowieckiego i Mikołaja Sępa Szarzyńskiego 53, a zaczerpnięty został z Księgi Izajasza (Iz 44, 22), gdzie czytamy: „Zgładziłem złość twoją jako obłok, a grzechy twoje

\footnotetext{
Nova”, t. VI), s. 85. Zob. też J. Sokolski, Bogini. Pojęcie. Demon. Fortuna w dzietach autorów staropolskich, Wrocław 1996.

53 Por. fragment z Setnika... Grabowieckiego brzmi następująco: „Ciebie szukam, mój Panie, / chcąc ci zlecić swą trwogę, / lecz Cię naleźć nie mogę, / bo zawżdy obłok wstanie / z mych grzechów, tłumiąc me w Tobie ufanie, / i światło mi zasłania / Twoje, o słońce wieczne!" (Id., Rymy duchowne I, 31, w. 6-12, w: Id., Rymy duchowne, wyd. K. Mrowcewicz, Warszawa 1996 (BPS, t. V). U Sępa Szarzyńskiego w Sonecie I O krótkości i niepewności na świecie żywota cztowieczego czytamy: „A ja, co dalej, lepiej cień głęboki / błędów mych widzę, które gęsto jędzą / strwożone serce ustawiczną nędzą, / i z płaczem ganię młodości mej skoki." (w. 5-8). Wszystkie cytaty z poezji Szarzyńskiego pochodzą z: M. Sęp Szarzyński, Poezje zebrane, wyd. R. Grześkowiak, A. Karpiński, współpr. K. Mrowcewicz, Warszawa 2001 (BPS, t. XXIII).
} 
jako mgłę" 54 . Jefte, pogrążony w ciemnościach, kroczy po mrocznych ścieżkach:

Po krzywych skałach dziwnie cię wodzi, gdzie noga twoja nieraz ugodzi na ostry kamień błędu śliskiego.

(w. 988-990)

Czy jednak kroczy sam? Zdanie to wymaga podmiotu, bo nie jest nim przecież — jak podpowiadałaby gramatyka — „mgła”, występująca jako podmiot w zdaniu poprzednim. „Dziwnie cię wodzi” (kto lub co?). Jest to znów bliżej niesprecyzowany „wróg jakis””, który, „dziwnie”, a zatem w sposób niezwykły, ponadnaturalny, prowadzi Jeftego po ostrych skałach wśród mroków.

Raz tylko mówi się w tragedii Zawickiego o Bogu jako o sprawcy ludzkich losów. Jednak kim jest ten nie-bóg, który przecież nie ma na celu dobra człowieka, a jego domeną bynajmniej nie jest łagodność, a wręcz niszczycielska siła? Nie przemawia do człowieka „lekkim powiewem" 55 , lecz

Tak Pan Bóg na współ rzeczy człowiecze obraca

jako znikomy wicher swym pędem wywraca

drzewa leśne i jako zimne śniegi tają;

widząc słoneczne koła, w rzeki uciekają.

(w. 1013-1016)

Od kogo zatem pochodzi przedsięwzięcie Jeftego, jeśli nie od Pana — od wroga czy Fortuny? Kim jest ten zagadkowy nieprzyjaciel, o którym w apostrofie do Jeftego wspomina w piątej pieśni chór? Na pewno nie są to synonimy Opatrzności, ale jej przeciwieństwa, które niosą konotacje demoniczne i tworzą obraz tajemniczej siły kierującej ludzkim

54 Biblia święta, księgi Starego i Nowego Zakonu..., Brześć 1563 (druk. M. Radziwiłła Czarnego). Nie wiemy, z jakich tłumaczeń Biblii korzystał polski poeta. Wiele wskazuje na tzw. „Biblię brzeską”, w której Jefte — podobnie jak w tragedii Zawickiego - nazwany został hetmanem.

55 Warto w tym kontekście powołać się na fragment 1 Księgi Królewskiej (19, 11 13), który opisuje, że Eliasz rozpoznał obecność Boga nie w potężnym wietrze, ale właśnie w lekkim powiewie. 
losem oraz posiadającej cechy łatwe do przypisania mocom ciemności. Tak więc Opatrzność została nie tylko wykluczona z odpowiedzialności za sytuację Jeftego, ale i jej miejsce zastąpiła nieznana, irracjonalna, ciemna siła rządząca światem.

Tkanka filozoficzna — na równi z teologiczną — stała się częścią dzieła. W rozmowach bohaterów oraz refleksjach zawartych w pieśniach chóru przewijają się motywy ludzkiego szczęścia, zmiennego jak pogoda (w. 775-776) i pory roku (w. 777-778), oraz nieszczęść, nękających człowieka, następujących po sobie niczym fala za falą (w. 119-120), dzień za dniem (w. 121-122). Dla tych, którzy popadli we władanie Fortuny, jedynymi środkami zaradczymi stają się virtus (cnota) i constantia (stałość). Powie Ifis: „Mam lekarstwo wielkie: / całe sumnienie nosić na przypadki wszelkie" (w. 519-520). Cnota jest jednak nie tylko sposobem na odmienność Fortuny, ale i gwarancją nagrody wiecznej. Nie bez przyczyny chór w ostatniej pieśni skieruje apostrofę do Ifis:

\footnotetext{
Panno umysłu męskiego,

krzywda szczęścia omylnego

obcina-ć kwitnące lata,

nagle cię zdejmując z świata,

lecz taką ujmę żywota

tym więcej bujna twa cnota

po śmierci hojnie-ć nagrodzi.

(w. 1219-1225)
}

Ten w gruncie rzeczy płytki optymizm, że filozofia stoicka jest w stanie przynieść ukojenie, przewartościowują rodzice bohaterki. Widać to wyraźnie w postawie Jeftego, kiedy gardzi on leczniczym działaniem czasu oraz „stateczną myślą”, co podczas rozmowy wyrzuca mu Symachus: „Niestateczna myśl to wszytko sprawuje, / z której pochodzi błąd, co wszystko psuje" (w. 647-648). Do stoickiej recepty odniesie się także Storge. To zaskakujące, że w zamykającej tragedię rozmowie z posłem wyrazi ona - wbrew postawie własnej córki — dezaprobatę wobec stałości: „a im stalszym umysłem zniosła tę śmierć swoję, / tym ciężej utrapioną frasuje myśl moję" (w. 1329-1330).

W tragedii słychać też tony sceptyczne, zwłaszcza w wypowiedziach odnoszących się do możliwości poznania przez człowieka zamiarów 
Opatrzności. Bohaterom tragedii towarzyszy refleksja, że ludzkie sądy o świecie to jedynie „fałszywe cienie” prawdziwych rzeczy. Prawdę tę pierwszy wypowiedział Jefte:

Co miło bywa za wejrzeniem pierwszym.

to kiedy człowiek swym rozsądkiem szerszym

uważa pilno: z żółcią być zmieszano

obaczy, co mu przedtym cukrowano.

(w. 605-608)

Sprawy złudne zdają się niczym słodki miód. Zasadę tę przedstawiła Storge. Kiedy poseł zapewnia ją, że Ifis ze stoickim spokojem zniosła śmierć, mówi:

Jeśliże co dobrego jej się tam przydało,

szczęście swoję okrutność przyszłą cukrowało,

które więc zwykło srogą truciznę nakrywać

słodkim miodem; nakrytą, da człeku pożywać.

(w. 1265-1268)

Jan z Zawidza był współczesnym Kochanowskiego i Sępa Szarzyńskiego. Jak słusznie zwróciła uwagę Janina Abramowska, z poezją Sępową łączy utwór Zawickiego klimat dramatyzmu konfesyjnego ${ }^{56}$. Nie brak, oczywiście, w polskiej tragedii dosłownych zapożyczeń z twórczości Sępa. W skardze Ifis: „O! jako nieszczęśliwe niewiasty sie rodzą, I które, choć dobrze żyją, przedsię ludziom szkodzą” (w. 513-514) można znaleźć reminiscencje z Sonetu I: „O moc, o rozkosz, o skarby pilności, / choćby nie darmo były, przedsie szkodzą" (w. 9-10). Związek poezji Sępa z utworem Zawickiego jest jednak głębszy. Oba teksty wyrosły z podobnych założeń. Ich podobieństwo zasadza się na postawie człowieka wobec świata, postawie, którą cechuje sceptycyzm poznawczy. Wiedza ludzka to przecież jedynie złudzenia i pozory, gdyż „żądzą zwiedzione / myśli cukrują nazbyt rzeczy one, / które i mienić, i muszą sie psować" (Sonet V, w. 2-4).

Fascynację twórczością poety z Czarnolasu bezbłędnie wyczuwa każdy czytelnik dramatu Zawickiego. W polskim Jeftesie słychać w rów-

56 Por. J. Abramowska, op. cit., s. 89. 
nym stopniu wiersze z Trenów jak i z Psatterza Dawidowego. Narzekania Storge na zły los, który w życiu nie oszczędził jej cierpień:

Nigdy mi sie tak pięknie nie stawity prządki żywotne, by mię kiedy były

z płaczu, z kłopotów, z frasunków wyrwały [...]

(w. 107-109),

wykazują podobieństwa do liryki funeralnej Jana Kochanowskiego:

Wszytki pła cze, wszytki łzy Heraklitowe

I lamenty, i skargi Symonidowe,

Wszytki troski na świecie, wszytki wzdychania,

I żale, i f r a su n ki, i rąk łamania

(Tren I, w. 1-4)

Z Trenów wybiera polski poeta głównie fragmenty przystające do określonych sytuacji dramatycznych. Ifis przed nocnym rozstaniem powierza matce „noc szczęśliwą” (w. 1207-1208), jak zwykła to czynić Orszulka, która „Nie poszła spać, aż pierwej matkę pozdrowiła / I zdrowie rodziców swych Bogu poruczyła" (Tren XII, w. 13-14).

Zawicki nie tylko wprowadza nawiązania intertekstualne do poezji Kochanowskiego, ale i prowadzi polemikę z liryką czarnoleską. Incipitem Trenu XII: „Żaden ojciec podobno barziej nie miłował / Dziecięcia, żaden barziej nad mię nie żałował" (w. 1-2) posłużyła się Ifis w rozmowie z ojcem: „Nikt przedtym dzieci własnych więcej nie miłował, / nikt w więtszej wadze nie miał, więcej nie szanował" (w. 503-504). Nawiązanie do trenu stało się tutaj okazją do uczynienia zarzutu wobec „niefortunnego ojca” ${ }^{57}$. Dalsze słowa córki Jeftego wyrażają bowiem rozczarowanie i skargę:

[...] teraz zaś ktoś mu serce do dzieci popsował, które on przede wszystkiem najbarziej miłował. (w. 505-506).

\footnotetext{
57 Słowa „niefortunny”, wchodzącego w skład cytatu z dedykacji w Trenach, używam w znaczeniu współczesnym.
} 
Również analiza metryki i strofiki każe — z jednej strony — dostrzec w Jeftesie wyraźne naśladowanie poezji czarnoleskiej ${ }^{58}$, a z drugiej - pozwala sytuować utwór Zawickiego w kręgu poezji uczonej. W swej tragedii Jan z Zawidza posłużył się czterema formatami wiersza sylabicznego. Zdecydowanie ulubionymi miarami są dla poety trzynastozgłoskowiec $(7+6)$, który występuje sześć razy, i jedenastozgłoskowiec $(5+6)$ pojawiający się nieco rzadziej, bo pięciokrotnie. Trzykrotnie wykorzystuje autor Jeftesa ośmio- i dwa razy — dziesięciozgłoskowiec. Każdy epizod i pieśń chóru są utrzymane w raz przyjętym metrum. Trzynastozgłoskowcem są pisane prolog i niektóre dialogi (kolejno: Poseł - Chór; Ifis - Jeftes - Symachus - Chorus; Jeftes - Kapłan; Storge - Jeftes - Ifis; Storge — Poseł), jedenastozgłoskowcem: scena Storge - Ifis, monolog Jeftego oraz część pierwszej pieśni chóru.

Ośmio- i dziesięciozgłoskowiec ograniczył poeta tylko do pieśni chóru. W wierszu ośmiozgłoskowym zamknął trzy pieśni, a w dziesięciozgłoskowym — dwie. Na tym tle wersyfikacyjnym wyróżnia się pieśń pierwsza (Który z Jordanu...). Jej druga część złożona została strofą saficką o formacie $5+6$ a a bb. Są to popularne w twórczości poety z Zawidza miary wierszowe. Spotykamy się z nimi również w Charites stowieńskiem, gdzie pojawiają się: dwukrotnie trzynastozgłoskowiec, parzyście rymowana strofa saficka oraz ośmiozgłoskowiec. Na uwagę zasługuje również poprzedzająca Jeftesa dedykacja pisana jedenastozgłoskowcem ze średniówką po piątej sylabie $(5+6)$. Zawicki posłużył się też wierszem białym $^{59}$, wysoko cenionym i rekomendowanym przez europejskie poetyki renesansowe ${ }^{60}$.

Rymy w tragedii Zawickiego są prawie wyłącznie dokładne (aa). Charakteryzują się konsekwentnie przestrzeganą paroksytonezą, obejmującą półtorej sylaby. Kilkakrotnie pojawiają się „trójki” i „czwórki rymowe", np.:

\footnotetext{
58 Por. J. Pelc, Jan Kochanowski w tradycjach literatury polskiej (od XVI do potowy XVIII w.), Warszawa 1965, s. 289.

$59 \mathrm{Na}$ temat recepcji wiersza białego w literaturze staropolskiej zob. M. Hanusiewicz -Lavallee, op. cit., s. 36.

${ }^{60}$ Zob. np. Joachim Du Bellay, Obrona i uświetnienie języka francuskiego, przeł. B. Otwinowska, w: Poetyka okresu renesansu. Antologia, wybór, wstęp i oprac. E. Sarnowska-Temeriusz, przypisy J. Mańkowski, E. Sarnowska-Temeriusz, Wrocław 1982 (BN II, 205), s. 147-148.
} 
[...] Zbraniać sie takiego

żywota - poszło coś na niemądrego,

nie uznać zasię - sprawa niewiernego,

nie umieć znosić — namniej niemężnego.

(w. 673-676)

W powyższym przykładzie dodatkowo umiejętnie wykorzystał polski pisarz elipsę. Wyrazy ważne dla prowadzonej myśli umieścił na końcu każdego wersu, podkreślając je dodatkowo rymami gramatycznymi. Często występują w Jeftesie pary rymowe, bazujące na użyciu tego samego wyrazu. Oto przykład:

\section{Storge}

Wyrwi mnie z tych kłopotów, z żalów i t r u d n o ści , niech stanę na brzegu dawnej bespieczności.

Jeftes

I tak jedno zabicie mnoży wiele złości, nieuchronnych kłopotów, tak wiele trud n ości .

(w. 1143-1146)

Epizod niespodziewanego spotkania wodza Galaadczyków z córką, jako dobry przykład ewokujący cudowność (w nomenklaturze Arystotelesowskiej — zaskoczenie $)^{61}$, wymieniał w swej poetyce włoski filolog, Lodovico Castelvetro ${ }^{62}$. Sam bohater Księgi Sędziów uznawany był za postać moralnie niejednoznaczną. Dość przypomnieć, że polski jezuita, Piotr Skarga, w swoich Żywotach świętych (1587), mimo że Jeftego „miedzy święte kładzie”" ${ }^{3}$ jako bogobojnego sędziego, wyraża jednak szereg wątpliwości:

${ }^{61}$ W tekstach włoskich teoretyków renesansu, komentujących Poetykę Arystotelesa, „cudowność” utożsamiona została z „zaskoczeniem”. Na temat relacji zachodzących między tymi pojęciami zob. B. Niebelska, Cudowność, paralogizm i koncept, w: Koncept w kulturze staropolskiej, red. L. Ślęk, A. Karpiński, W. Pawlak, Lublin 2005, s. 29-45.

62 Zob. L. Castelvetro, Poetyka Arystotelesa: przetożona i skomentowana, przeł. T. Dobrzyńska, w: Poetyka okresu renesansu..., s. 358.

63 Formuły tej użył Skarga w stosunku do św. Pawła, który w Liście do Hebrajczyków $(11,32)$ umieścił Jeftego pośród mężnych w wierze chrześcijan. 
Jedni go w tym ganią, drudzy go obmawiają, a mówią, iż to z Ducha Bożego i z osobnego natchnienia i objawienia uczynił. Jakkolwiek jest, te są rzeczy pewne, iż w nauce katolickiej nieodmienne: pierwsze, iż się krwi ludzkiej Bogu ofiarować nie godzi i brzydzi się Pan ofiarą taką mężobójską. Druga, iż co się źle a nieroztropnie Panu Bogu obiecuje, to się jeszcze w większym grzechu pełni. [...] Trzecie, iż śluby, które kto Panu Bogu czyni w rzeczach przystojnych, winien je pełnić i takie obietnice wielce się Panu podobają. ${ }^{64}$

Przedmiotem swojej tragedii szkocki humanista uczynił więc historię kojarzącą się z klimatem duchowym Europy XVI wieku, nękanej konfliktami religijnymi. Postać Jeftego okazała się szczególnie atrakcyjna i dla polskiego poety. Dzięki translacji Jana Zawickiego, o którym do niedawna nie wiedzieliśmy nic pewnego, twórczość rodzima - na równi z innymi literaturami - otrzymała utwór prezentujący aktualne kontrowersje religijne i zapowiadający dramat sumienia, jaki już wkrótce na stałe miał zagościć w dziełach kolejnej epoki.

\section{Providence and the Enemy. About Jan Zawicki and his Tragedy Jeftes}

The article is devoted to the tragedy Jeftes by Jan Zawicki, which is the translation of the drama Jephthtes, sive votum written in Latin by the Scottish humanist, George Buchanan. Jan Zawicki was a poet living at the end of XVI c. He was a student of the Cracow Academy and was expelled for many offences recorded in the Acta rectoraria ab anno 1580 ad annum 1618. The author also wrote the cycle of songs known as Charites stowieńskie. The tragedy Jeftes by Jan Zawicki shows parallels and connections in the areas of Theme and topic, with another Polish drama, entitled Jefte, which was staged in the presence of bishop Baranowski in Pułtusk on the 23rd of August, 1599. The article shows features of the style of the author of the Polish translation and describes issues related to the philosophical and theological tissue of this translation.

Translated by Agnieszka White

${ }^{64}$ P. Skarga, Żywoty świętych..., t. I, wyd. ks. K. Moniewski, druk. oo. Mechitarzystów, Wiedeń 1859, s. 481-482. 